\title{
Third Party Healthcare Payer
}

National Cancer Institute

\section{Source}

National Cancer Institute. Third Party Healthcare Payer. NCI Thesaurus. Code C70691.

An organization that pays or insures healthcare expenses on behalf of beneficiaries or recipients. An individual pays a premium for such coverage in all private and in some public programs; the payer organization then pays bills on the beneficiary's behalf. 